\title{
Cutaneous furuncular myiasis: Human infestation by the botfly
}

\author{
Bryan Jacobs BSE, David L Brown MD FACS
}

\begin{abstract}
B Jacobs, DL Brown. Cutaneous furuncular myiasis: Human infestation by the botfly. Can J Plast Surg 2006;14(1):31-32.

Dermatobia hominis, the botfly, is indigenous to Central and South America. Its usual host is a mammal, often a horse or cow. Cutaneous furuncular myiasis, human infestation by the botfly, has rarely been reported. Symptoms of infestation include a locally painful, firm furuncular lesion, often with a centrally located pore. Due to their infrequent occurrence, these lesions are often misdiagnosed as cellulitis, leishmaniasis, furunculosis, staphylococcal boil, insect bite or sebaceous cyst - conditions with similar presentations. The present case reiterates the need to think of 'zebras' when hearing 'hoof beats' that may have originated in a different land.
\end{abstract}

Key Words: Botfly; Furuncular myiasis; Sebaceous cyst

\section{La myiase furonculeuse cutanée : Une infestation humaine par l'hypoderme}

\begin{abstract}
Le Dermatobia hominis, ou hypoderme, est indigène à l'Amérique centrale et à l'Amérique du Sud. Son hôte habituel est un mammifère, souvent un cheval ou une vache. La myiase furonculeuse cutanée, une infestation humaine par l'hypoderme, a rarement été déclarée. Les symptômes d'infestation incluent une lésion furonculeuse ferme et douloureuse, souvent accompagnée d'un pore central. En raison de leur occurrence peu fréquente, ces lésions sont souvent mal diagnostiquées comme une cellulite, une leishmaniose, une furonculose, un furoncle à staphylocoque, une piqûre d'insecte ou un kyste sébacé, des problèmes aux manifestations similaires. Le présent cas rappelle le besoin de garder l'esprit ouvert en présence d'une infestation qui a pu trouver son origine sur un autre territoire.
\end{abstract}

\section{CASE PRESENTATION}

A 25-year-old man presented to his primary care physician with what appeared to be an infected sebaceous cyst on his posterior scalp. Drainage was performed and a short course of oral antibiotics was administered. The infection recurred, and he was referred for a surgical consultation. Physical examination was again consistent with an infected sebaceous cyst, and repeat drainage was performed in the office setting. Five weeks later, after resolution of the infection, he was scheduled for formal excision of the presumed cyst. An elliptical incision was made over the subcutaneous mass to include the identified 'punctum'. Upon subcutaneous dissection, a black, $1.4 \mathrm{~cm}$ long foreign body was encountered (Figure 1). It appeared to be a cocoon or insect larva. The surrounding tissues were excised, and the wound was closed. Postoperative questioning of the patient revealed that he had traveled to Costa Rica on his honeymoon three weeks before the initial infection.

Upon microscopic examination, the dermatopathologist described the specimen as myiasis, with the identification of larval elements. The specimen was forwarded to the Centers for Disease Control and Prevention (USA), who confirmed this diagnosis due to the presence of golden-colored chitinous spines and smooth muscle cells seen in the body of the larva (Figure 2).

\section{DISCUSSION}

The means of infection by the botfly are unique. The female botfly first captures an arthropod, usually a mosquito, and lays her eggs on its body - a phenomenon called phoresia. When the mosquito lands on a mammal and the eggs are deposited on the skin, the body heat causes the eggs to hatch. In a matter of minutes, the larvae penetrate the skin, often through the mosquito bite or along a hair follicle (1). While in the skin, the larvae breathe through a small opening in the skin, which they also use to dispose of their serosanguinous feces. They develop concentric rows of small black spicules that assist in anchoring them in place, and can grow up to $3 \mathrm{~cm}$ in length (2). After a period of six to 12 weeks, the larvae leave, exiting their host through the original hole and fall to the ground, entering the earth to pupate.

Thus, infection with the human botfly is usually a selflimiting condition, but nonetheless, an increasingly painful one. In some instances, the infested individual reports detectable subcutaneous movements (3). It is worth noting that a similar organism found in tropical Africa, the tumbu fly (Cordylobia anthropophaga), causes a comparable form of myiasis by contaminating clothing while drying.

There have been only a small number of reports of furuncular myiasis in the North American literature. Infections have usually been found to occur on the limbs, but have also occurred on the scalp, neck, back, breast, scrotum, tongue and eye (4-9). Several fatalities have been reported as a result of the larvae moving through the fontanelles of infants. Although there are few reported cases overall, a wide range of methods for management have been proposed.

Surgical removal is the most common and preferred option $(2,10)$. Interestingly, bacterostatic agents are produced in the gut of the larvae, making secondary infections following surgery unusual (2). A variety of nonsurgical methods have shown success, especially in the early stages of larval development. Suffocation, via the application of petroleum jelly, pork fat, fingernail polish, tape or beeswax to obstruct the larva's breathing hole, can encourage the larva to move to the surface 


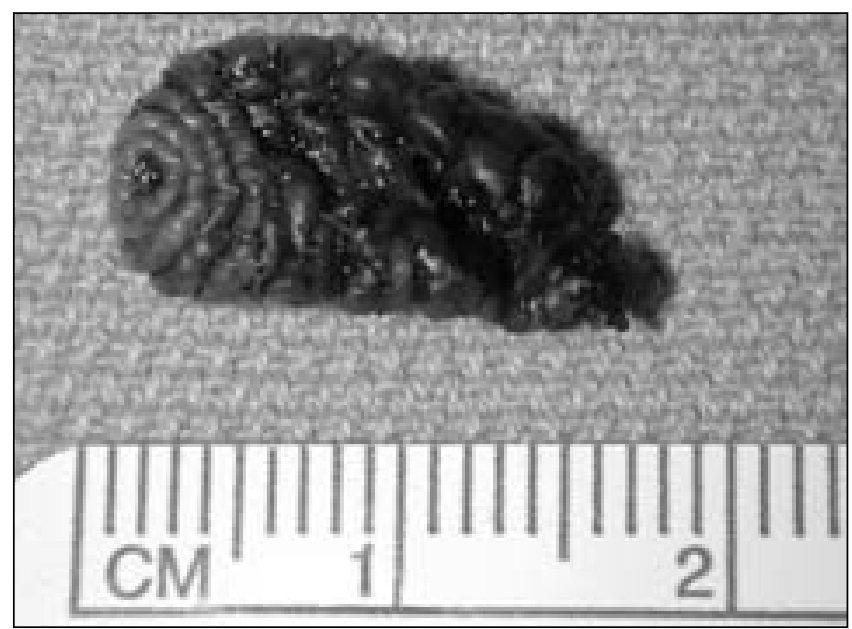

Figure 1) Body of the deceased botfly larva removed from the posterior scalp of the patient

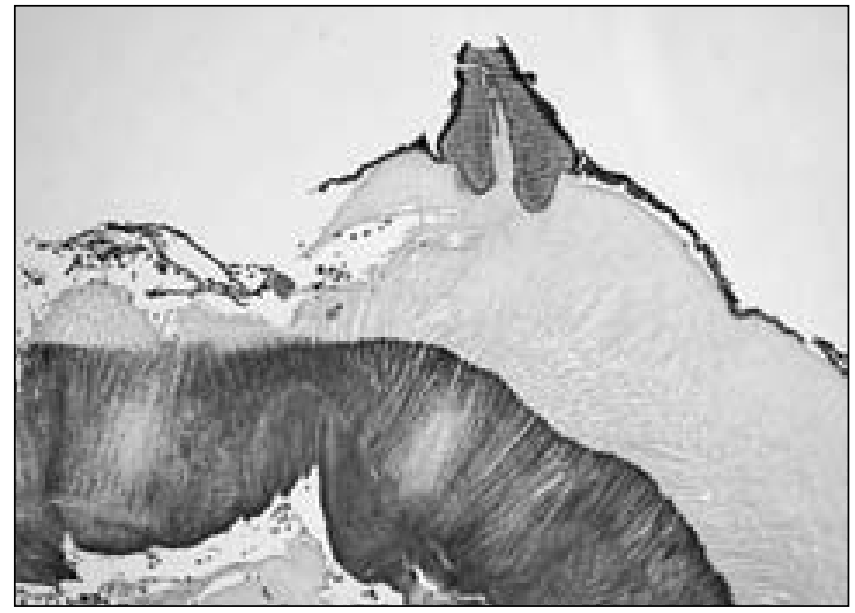

Figure 2) Hematoxylin and eosin-stained photomicrograph section revealing the presence of a chitinous spine on the surface of the botfly larva. An internal layer of muscle is also identifiable, and is characteristic of the botfly (original magnification $\times 20$ ) of the skin. Raw meat, applied to the site for several hours, is thought to create an oxygen deficiency and act as a medium into which the larva can migrate (6).

\section{CONCLUSION}

The botfly is native to Central and South America. Because it is not indigenous to the United States or Europe, infection by its larvae is not a commonly recognized condition. Therefore, when human myiasis does occur, it is often misdiagnosed. Given the ever-increasing amount of international travel, the list of differential diagnoses associated with any one presentation lengthens. However, human botfly infestation is becoming more commonly seen in nonindigenous areas. Medical professionals should keep this interesting diagnosis in their differential when examining new onset subcutaneous masses that are temporally related to international travel to endemic regions.

\section{REFERENCES}

1. Emborsky ME, Faden H. Ophthalmomyiasis in a child. Pediatr Infect Dis J 2002;21:82-3.

2. Sampson CE, MaGuire J, Eriksson E. Botfly myiasis: Case report and brief review. Ann Plas Surg 2001;46:150-2.

3. Tamir J, Haik J, Schwartz E. Myiasis with Lund's fly (Cordylobia rodhaini) in travelers. J Travel Med 2003;10:293-5.

4. Maier H, Honigsmann H. Furuncular myiasis caused by Dermatobia hominis, the human botfly. J Am Acad Dermatol 2004;50(Suppl 2):S26-30.

5. Harbin LJ, Khan M, Thompson EM, Goldin RD. A sebaceous cyst with a difference: Dermatobia hominis. J Clin Pathol 2002;55:798-9.

6. Brewer TF, Wilson ME, Gonzalez E, Felsenstein D. Bacon therapy and furuncular myiasis. JAMA 1993;270:2087-8

7. Massey RL, Rodriguez G. Human scrotal myiasis: Botfly infestation. Urol Nurs 2002;22:315-7.

8. Kahn DG. Myiasis secondary to Sermatobia hominis (human botfly) presenting as a long-standing breast mass. Arch Pathol Lab Med 1999;123:829-31.

9. Goodman RL, Montalvo MA, Reed JB, et al. Photo essay: Anterior orbital myiasis caused by human botfly (Dermatobia hominis). Arch Ophthal 2000;118:1002-3.

10. Richards KA, Brieva J. Myiasis in a pregnant woman and an effective, sterile method of surgical extraction. Dermatol Surg 2000;26:955-7. 